Research article

\title{
Metal fractionation in sludge from sewage UASB treatment
}

\author{
A.F.M. Braga ${ }^{\text {a, }}{ }^{*}$, M. Zaiat ${ }^{\text {a }}$, G.H.R. Silva ${ }^{\text {b }}$, F.G. Fermoso ${ }^{c}$ \\ a Biological Processes Laboratory, Center for Research, Development and Innovation in Environmental Engineering, São Carlos School of Engineering (EESC), \\ University of São Paulo (USP), Engenharia Ambiental - Bloco 4-F, Av. João Dagnone, 1100 - Santa Angelina, 13.563-120, São Carlos, SP, Brazil \\ ${ }^{\mathrm{b}}$ Department of Civil and Environmental Engineering, University, São Paulo State University (UNESP), Av. Engenheiro Luiz Edmundo Carrijo Coube, 14-01, \\ Vargem Limpa, 17033-360, Bauru, SP, Brazil \\ ${ }^{\mathrm{c}}$ Instituto de la Grasa (C.S.I.C.), Campus Universitario Pablo de Olavide, Edificio 46, Ctra. de Utrera, Km. 1, 41013, Sevilla, Spain
}

\section{A R T I C L E I N F O}

\section{Article history:}

Received 6 October 2016

Received in revised form

23 January 2017

Accepted 28 January 2017

Available online 11 February 2017

\section{Keywords:}

Metal fractionation

Sewage UASB reactor

Specific methanogenic activity

Metal sequential extraction

\begin{abstract}
A B S T R A C T
This study evaluates the trace metal composition and fractionation in sludge samples from anaerobic sewage treatment plants from six cities in Brazil. Ten metals were evaluated: $\mathrm{Ni}, \mathrm{Mn}, \mathrm{Se}, \mathrm{Co}, \mathrm{Fe}, \mathrm{Zn}, \mathrm{K}, \mathrm{Cu}$, $\mathrm{Pb}$ and $\mathrm{Cr}$. Specific methanogenic activity of the sludge was also evaluated using acetic acid as the substrate. Among the essential trace metals for anaerobic digestion, Se, $\mathrm{Zn}, \mathrm{Ni}$ and $\mathrm{Fe}$ were found at a high percentage in the organic matter/sulfide fraction in all sludge samples analyzed. These metals are less available for microorganisms than other metals, i.e., Co and $\mathrm{K}$, which were present in significant amounts in the exchangeable and carbonate fractions. $\mathrm{Cu}$ is not typically reported as an essential metal but as a possible inhibitor. One of the samples showed a total $\mathrm{Cu}$ concentration close to the maximal amount allowed for reuse as fertilizer. Among the non-essential trace metals, $\mathrm{Pb}$ was present in all sludge samples at similar low concentrations and was primarily present in the residual fraction, demonstrating very low availability. $\mathrm{Cr}$ was found at low concentrations in all sludge samples, except for the sludge from STP5; interestingly, this sludge presented the lowest specific methanogenic activity, indicating possible Cr toxicity.
\end{abstract}

๑) 2017 Elsevier Ltd. All rights reserved.

\section{Introduction}

Sanitation systems are still expanding in Brazil. The Brazilian National Department of Environmental Sanitation gathered data from $67 \%$ of Brazilian municipalities, representing $91.1 \%$ of the total urban population. They reported that $48.6 \%$ of the domestic sewage is collected, of which $69.4 \%$ is treated, resulting in an annual volume of 3.624 billion $\mathrm{m}^{3}$ (Secretaria Nacional de Saneamento Ambiental, 2014). In addition to overcoming the gap between the sewage that is collected and the amount sanitized in Brazil, the quality of effluent produced by sewage treatment plants (STPs) must be improved to comply with the required standards. The Brazilian standard established a maximum biochemical oxygen demand (BOD) of $120 \mathrm{mg} \mathrm{L}^{-1}$ for the effluent or a minimum treatment efficiency of $60 \%$ for STPs (Brasil, 2011).

The application of anaerobic digestion to sewage treatment, especially using Up-flow Anaerobic Sludge Bed (UASB) reactors, has gained attention since the 1980s. UASB reactors present an

\footnotetext{
* Corresponding author.

E-mail address: adrianabraga@usp.br (A.F.M. Braga).
}

advantageous solution for sewage treatment in countries with a tropical climate because the system is easy to maintain, produces a low sludge amount and has a favorable energy balance because it does not require heating (Foresti et al., 2006; Foresti, 2002; Lettinga et al., 1983). The anaerobic treatment of sewage has been established in warm climate countries in development, and UASB reactors are present in many sewage treatment plants across countries such as Brazil, India and Colombia due its robustness (Foresti, 2002; Jordão and Volschan, 2004; Khan et al., 2011).

Von Sperling and Oliveira (2009) evaluated the performance of 166 full-scale STPs in Brazil using predominantly anaerobic or aerobic treatment technologies with and without post-treatment. The authors found that the performance of STPs demonstrated variability regarding the chemical oxygen demand (COD) removal efficiency, even among systems adopting the same technologies, and occasionally, none of the employed post-treatments was sufficient to achieve the desired effluent quality. The literature reviewed by Khan et al. (2011) also showed that even applying post-treatment, the effluent of many treatment systems did not comply the standards for effluent discharge/reuse for the variables biochemical oxygen demand (BOD) and total soluble solids (TSS).

Efforts have been made to overcome the possible limitations in 
STP performances, especially those with implemented UASB reactors (Chernicharo et al., 2015). The optimal performance of an anaerobic digester in an STP is a function of the environment (temperature, $\mathrm{pH}$, nutrients, trace metals), operation (loading, retention time, mixing), reactor (configuration, geometry, size), inoculum (volume, activity, adaptation) and substrate (composition, strength) (Chong et al., 2012).

One overlooked parameter is the role of trace metals in anaerobic digestion performance. The fate of trace metals in anaerobic digesters is typically studied under high trace metal concentrations that might inhibit the process. However, the fate of trace metals as micronutrients is also typically overlooked. The nutritional requirement of the microorganisms involved in anaerobic systems plays an important role in the process because it affects their growth rate and drives metabolic pathways, consequently determining the efficiency of organic matter conversion and methane $\left(\mathrm{CH}_{4}\right)$ production. Trace metals are micronutrients that are primarily involved in enzyme activities, and microorganisms have specific values for optimal and limiting concentrations (Madigan et al., 2012). In anaerobic digestion, Fe and $\mathrm{Ni}$ act as cofactors of hydrogenases, participating in the acidogenic and the methanogenic hydrogenotrophic stages of $\mathrm{CH}_{4}$ production (Vignais and Colbeau, 2004). Kida et al. (2001)demonstrated that limiting the amounts of $\mathrm{Ni}$ and $\mathrm{Co}$ decreases the concentration of the coenzymes responsible for acetic acid conversion to methane. Co was also studied in the anaerobic degradation of methanol, and its supplementation enhanced the specific methanogenic activity of microorganisms (Fermoso et al., 2010; Florencio et al., 1993; Zandvoort et al., 2004). Worm et al. (2009) demonstrated the importance of Mo, W and Se in the degradation of propionate in an anaerobic system. Takashima et al. (2011) found that the requirement of $\mathrm{Fe}, \mathrm{Co}, \mathrm{Zn}$ and $\mathrm{Ni}$ was 2.2, 3.2, 4.9 and 7.8 times higher, respectively, for thermophilic fermentation of glucose than for mesophilic fermentation.

Research on the characterization of trace metals in anaerobic digesters from STPs has increased only in the last few years, along with concern about the disposal of the sludge generated in these plants (Jones et al., 2014; Liu and Sun, 2013; Nogueirol et al., 2013; Souza et al., 2014; Yang et al., 2014). Although trace metals may be present at high concentrations in sludge that receives low loads of trace metals over a long period, these trace metals may not be bioavailable for microorganisms. The trace metals can be potentially more bioavailable for microorganisms as they become more weakly associated with the sludge.

Several operationally defined techniques have been applied to evaluate metal fractionation, thus evaluating their availability in solid media (Hullebusch et al., 2005). Sequential extraction techniques have been the most widely used methods to study metal distribution in sludge, solid and sediments (Filgueiras et al., 2002). In these sequential extractions, conditions are changed in the order of increasing reactivity so that the successive fractions obtained correspond to metal species with decreasing mobility. Many different configurations have been proposed for sequential extraction techniques, depending on the matrix and environmental conditions, and the modified Tessier method is the most widely used technique for anaerobic sludge (Hullebusch et al., 2005). The modified Tessier method defines four main fractions: the exchangeable fraction, the bound to carbonate fraction, the bound to organic matter and sulfide fraction and the residual fraction. The exchangeable fraction of trace metals is related to the trace metals that are only adsorbed into the sludge, and they can be dissolved with a neutral solution; trace metals bound to carbonates are primarily related to carbonate species, and they can be dissolved using a weakly acidic solution. Thus, metals present in these two fractions are readily available. The fraction bound to organic matter and sulfide are metals related to sulfide species and species already incorporated into the microorganisms and the feedstock, which are likely released under strong oxidizing conditions. The residual fraction is related to metals that are fixed inside the mineral structure and are not likely released from the sludge until a strong acid is added.

The goal of the present study was to evaluate the distribution of different trace metals through the four mentioned fractions in sludge from sewage UASB reactors. The total concentration and different fractions of trace metals in six sewage UASB reactors in Brazil were analyzed and correlated with the specific methanogenic activity (SMA) of the studied sludges.

\section{Materials and methods}

\subsection{Sewage UASB reactor sludge}

Samples from six UASB reactors were collected from STPs of six cities in Brazil, located in Southeast Brazil (latitudes 20 to $22^{\circ}$ south), in the states of São Paulo and Minas Gerais, and these areas are under a tropical climate with temperatures varying from 12 to $33{ }^{\circ} \mathrm{C}$.

All STPs performed a pre-treatment of the sludge to remove coarse materials, sand and grit. The STPs used a Parshall flume containing a $\mathrm{pH}$ controller to measure the flow rate and to maintain the inlet $\mathrm{pH}$ value at approximately 7.0. In these plants, there was a primary treatment process for removing grease and fat, and then, a UASB reactor was operated followed by an activated sludge and by a physical-chemical post-treatment. A general characterization of the UASB sludge samples is presented in Table 1.

\subsection{General analysis}

Before the analytical procedures, $50 \mathrm{~mL}$ of sludge was centrifuged at $6000 \mathrm{rpm}$ for $10 \mathrm{~min}$ and the supernatant was discarded. The determination of total solids (TS) and volatile total solids (VTS) was performed according to APHA et al. (2005). To measure the $\mathrm{pH}$, alkalinity and volatile acidity, the sludge was further diluted to $50 \mathrm{~mL}$ with ultra-pure water and mixed for $1 \mathrm{~h}$ at $150 \mathrm{rpm}$. The $\mathrm{pH}$ was measured using a Qualxtron pH-meter (model 8010, Hexis Científica, Brazil). Alkalinity was measured following the method of Ripley et al. (1986). Volatile acidity was measured according to DilLallo and Albertson (1961).

\subsection{Total metal extraction}

To determine the total metal concentration in sludge, $0.5 \mathrm{~g}$ of centrifuged sludge ( $6000 \mathrm{rpm}$ for $10 \mathrm{~min}$ ) and only the solid phase was digested in Teflon ${ }^{\circledR}$ vessels with $5 \mathrm{~mL}$ of $\mathrm{HNO}_{3}(2 \mathrm{M})$ along with $2 \mathrm{~mL}$ of $\mathrm{H}_{2} \mathrm{O}_{2}$ (30\%) (Bizzi et al., 2014) in a microwave (Four Speed, Berghof GmbH, Germany) under the conditions described in Table 2. After the samples were digested, they were filtered (Whatman ${ }^{\circledR} 589 / 1$, Sigma-Aldrich, MO, USA) and diluted to $100 \mathrm{~mL}$ in volumetric flasks. The metals in the samples were determined by inductively coupled plasma-optical emission spectroscopy (ICPOES; Optima 8000, Perkin Elmer, USA).

\subsection{Sequential metal extraction}

The modified Tessier method (van der Veen et al., 2007)was used to evaluate the distribution of trace metals in four fractions: exchangeable (EXC); bound to carbonates (CARB), bound to organic matter + sulfides $(\mathrm{OM}+\mathrm{S})$ and residual (RES). Thus, the sludge volume required to obtain approximately $1 \mathrm{~g}$ of TS was centrifuged (6000 rpm for $10 \mathrm{~min}$ ). After this procedure, the supernatant was 
Table 1

Physical-chemical characteristics of sludge samples from UASB reactors.

\begin{tabular}{|c|c|c|c|c|c|c|}
\hline \multirow[t]{2}{*}{ Parameter } & \multicolumn{6}{|c|}{ Sludge Samples } \\
\hline & STP1 & STP2 & STP3 & STP4 & STP5 & STP6 \\
\hline TS (g g-wet ${ }^{-1}$ ) & $0.148 \pm 0.030$ & $0.103 \pm 0.021$ & $0.160 \pm 0.025$ & $0.170 \pm 0.026$ & $0.193 \pm 0.029$ & $0.155 \pm 0.023$ \\
\hline TVS (g g-wet $\left.{ }^{-1}\right)$ & $0.093 \pm 0.017$ & $0.076 \pm 0.016$ & $0.097 \pm 0.012$ & $0.105 \pm 0.013$ & $0.110 \pm 0.012$ & $0.094 \pm 0.013$ \\
\hline TVS/TS & 0.627 & 0.738 & 0.606 & 0.619 & 0.569 & 0.609 \\
\hline $\mathrm{pH}$ & $7.25 \pm 0.08$ & $6.77 \pm 0.05$ & $7.37 \pm 0.01$ & $7.08 \pm 0.01$ & $6.93 \pm 0.06$ & $6.94 \pm 0.07$ \\
\hline Partial alkalinity $\left(\mathrm{mg} \mathrm{CaCO}_{3} \mathrm{gTS}^{-1}\right)$ & $10.89 \pm 0.84$ & $25.02 \pm 0.00$ & $47.92 \pm 2.71$ & $12.50 \pm 0.63$ & $8.21 \pm 0.17$ & $15.15 \pm 0.98$ \\
\hline Total alkalinity $\left(\mathrm{mg} \mathrm{CaCO}_{3} \mathrm{gTS}^{-1}\right)$ & $21.98 \pm 1.40$ & $53.74 \pm 3.93$ & $117.25 \pm 1.36$ & $31.48 \pm 2.84$ & $21.21 \pm 0.87$ & $28.50 \pm 1.38$ \\
\hline $\mathrm{IA} / \mathrm{TA}^{*}$ & 0.50 & 0.53 & 0.59 & 0.60 & 0.61 & 0.47 \\
\hline Volatile acidity ( $\mathrm{mg} \mathrm{CH} \mathrm{CHOH} \mathrm{gTS}_{3} \mathrm{COO}^{-1}$ & $13.14 \pm 2.77$ & $36.04 \pm 0.98$ & $31.11 \pm 8.53$ & $18.29 \pm 0.29$ & $14.75 \pm 0.55$ & $13.69 \pm 0.47$ \\
\hline Total Sulfur (mgS gTS $\left.{ }^{-1}\right)$ & $16.69 \pm 1.23$ & $26.81 \pm 0.04$ & $19.62 \pm 0.37$ & $21.07 \pm 2.21$ & $33.28 \pm 2.68$ & $27.46 \pm 0.97$ \\
\hline Sewage flow rate in the STP $\left(\mathrm{L} \mathrm{s}^{-1}\right)$ & 600 & 160 & 90 & 560 & 1050 & 40 \\
\hline Population served (hab) & 210,000 & 59,000 & 50,000 & 200,000 & 440,000 & 700 \\
\hline
\end{tabular}

"Ratio between the intermediate alkalinity (IA) and the total alkalinity (TA).

Table 2

Microwave conditions for sample digestion for total metal analysis.

\begin{tabular}{|c|c|c|c|c|c|}
\hline Stage & Temperature $\left({ }^{\circ} \mathrm{C}\right)$ & Pressure (psi) & Ramp (min) & Time (min) & Power (\%) \\
\hline 1 & 150 & 40 & 5 & 10 & 70 \\
\hline 2 & 160 & 40 & 2 & 10 & 80 \\
\hline 3 & 180 & 40 & 2 & 20 & 90 \\
\hline
\end{tabular}

discharged without analysis and the solid fraction was subjected to the sequential extraction scheme (Table 3 ).

The extraction of phases 1 (EXC) and 2 (CARB) was performed inside a glovebox workstation (UNIlab Plus, MBRAUN, Germany). Between the extractions, the liquid phase was separated by centrifugation at $4000 \mathrm{rpm}$ for $10 \mathrm{~min}$. The residual fraction was digested in a microwave under the conditions given in Table 2 . The metals in the samples were determined by ICP-OES (Optima 8000 , Perkin Elmer, USA).

\subsection{Metal determination}

As previously indicated, the metals in the samples from the total metal extraction and the sequential metal extraction were determined by ICP-OES (Optima 8000, Perkin Elmer, USA). The operational conditions of the ICP-OES spectrometer were RF power: $1300 \mathrm{~W}$, argon plasma flow rate: $8 \mathrm{~L} \mathrm{~min}^{-1}$, auxiliary argon flow rate: $0.3 \mathrm{~L} \mathrm{~min}^{-1}$, nebulizer argon flow rate: $0.80 \mathrm{~L} \mathrm{~min}^{-1}$ and sample flow: $1.0 \mathrm{~L} \mathrm{~min}^{-1}$. Yttrium (Y $324.227 \mathrm{~nm}: 1 \mathrm{mg} \mathrm{L}^{-1}$ ) was added as an internal standard, and the elements measured were as follows: Co $228.616 \mathrm{~nm}$ (axial view), Cr $205.560 \mathrm{~nm}$ (axial view), Cu $324.752 \mathrm{~nm}$ (axial view), Fe $239.562 \mathrm{~nm}$ (radial view), K $766.490 \mathrm{~nm}$ (radial view), Mg $280.271 \mathrm{~nm}$ (radial view), Mn 257.610 (axial view), Ni $231.604 \mathrm{~nm}$ (axial view), Pb $220.353 \mathrm{~nm}$ (axial view), S $181.975 \mathrm{~nm}$ (axial view), Se $196.026 \mathrm{~nm}$ (axial view) and $\mathrm{Zn}$ $213.857 \mathrm{~nm}$ (axial view). Each standard calibration curve was prepared with the respective matrix used in the extraction procedure.

\subsection{Specific methanogenic activity}

Batch assays were performed using $1 \mathrm{~g} \mathrm{~L}^{-1}$ acetic acid to determine the SMA of the six sludge samples without trace metal addition. Thus, the trace metal requirements were met by the existing trace metals in the sludge. Macronutrients $(\mathrm{N}, \mathrm{P}$, K) were added according to Angelidaki et al. (2009). Glass bottles with $250 \mathrm{~mL}$ of working volume and $350 \mathrm{~mL}$ of headspace were used. The assays were performed in triplicate in a chamber at a controlled temperature $\left(32.0 \pm 0.4{ }^{\circ} \mathrm{C}\right)$, and agitation was applied before measuring the pressure inside the bottles. The amount of biomass added to the bottles was $1.24 \pm 0.31 \mathrm{~g}$ TVS $\mathrm{L}^{-1}$. Control bottles, without substrate addition, were also prepared in triplicate. To ensure anaerobic conditions, the bottles' atmosphere was purged with a $\mathrm{N}_{2} / \mathrm{CO}_{2}$ gas mixture for 3 min.

The biogas production was monitored using a TPR-18 pressure transducer coupled to a BS 2200 interface (Desin Instruments, Barcelona, ESP). To confirm the biogas composition, which was expected to be $70 \% \mathrm{CH}_{4}$ and $30 \% \mathrm{CO}_{2}$, at the end of the assays, gaseous samples were analyzed using a GC 2010 chromatograph (Shimadzu $^{\circledR}$, Kyoto, Japan). The GC 2010 chromatograph contains a thermal conductivity detector, a Carboxen 1010 capillary column ( $\mathrm{L} \times \mathrm{I} . \mathrm{D} .30 \mathrm{~m} \times 0.53 \mathrm{~mm}$, average thickness $30 \mu \mathrm{m}$ ) and argon as the carrier gas at a flow rate of $12 \mathrm{~mL} \mathrm{~min}^{-1}$. The temperatures of the injector, column, and detector were $200^{\circ} \mathrm{C}, 130^{\circ} \mathrm{C}$, and $230^{\circ} \mathrm{C}$, respectively.

Using Origin 8.0 software (OriginLab ${ }^{\circledR}$, Northampton, MA, USA), the Boltzmann equation was adjusted to the raw data of the $\mathrm{CH}_{4}$ accumulated volume versus time. Then, the derivatives $(\mathrm{dV} / \mathrm{dt})$ for each point of the fitted Boltzmann curve versus time were calculated. Hence, the SMA values were obtained from the derivative values of the fitted curve using Equation (1), modified from Zinatizadeh et al. (2006):

Table 3

Conditions of the sequential extraction method applied to the sludge (modified from.van der Veen et al. (2007)).

\begin{tabular}{|c|c|c|c|c|}
\hline \multirow[t]{2}{*}{ Phase } & \multirow[t]{2}{*}{ Fraction } & \multirow[t]{2}{*}{ Extracting agent } & \multicolumn{2}{|l|}{ Extraction conditions } \\
\hline & & & Shaking time (min) & Temperature $\left({ }^{\circ} \mathrm{C}\right)$ \\
\hline 1 & Exchangeable (EXC) & $10 \mathrm{~mL} \mathrm{NH}_{4} \mathrm{CH}_{3} \mathrm{COO}(1 \mathrm{M}, \mathrm{pH} 7)$ & 60 & $20-25$ \\
\hline 2 & Carbonates (CAR) & $10 \mathrm{~mL} \mathrm{CH}_{3} \mathrm{COOH}(1 \mathrm{M}, \mathrm{pH} 5.5)$ & 60 & $20-25$ \\
\hline 3 & Organic matter + Sulfides $(\mathrm{OM}+\mathrm{S})$ & $5 \mathrm{~mL} \mathrm{H}_{2} \mathrm{O}_{2}(30 \% \mathrm{pH} 2)$ & 240 & 30 \\
\hline 4 & Residual (RES) & aqua regia $\left(\mathrm{HCl}: \mathrm{HNO}_{3} 3: 1\right)$ & - & - \\
\hline
\end{tabular}


$S M A\left(m g C O D-C H_{4} \cdot T^{-1} \cdot d^{-1}\right)=\frac{\frac{d V}{d t} \times f c_{S T P}}{V_{L} \times C_{T V S}}$

Where,

- $\mathrm{fC}_{\text {STP }}$ is the coefficient to convert the $\mathrm{CH}_{4}$ volume at standard temperature and pressure $\left(0{ }^{\circ} \mathrm{C}\right.$ and 1 bar $)$ to $\mathrm{COD}^{-} \mathrm{CH}_{4}$, which the value is $2.820 \mathrm{mgCOD}-\mathrm{CH}_{4} \cdot \mathrm{mL}_{-} \mathrm{CH}_{4}^{-1}$;

- $\mathrm{C}_{\mathrm{TVS}}$ is the concentration of sludge $\left(\mathrm{gTVS} \mathrm{L}^{-1}\right.$ ) add to the bottles as biomass seed.

\subsection{Statistical analyses}

Different statistical approaches were applied to analyze and verify the validity of the obtained data, using Statistica 64 software (Dell Inc., Tulsa, OK, USA). A Box-Whiskers plot was constructed to represent the total metal content data using the mean values, mean \pm standard error (SE) as the box limits, mean $\pm 2 *$ standard deviation (SD) for the whiskers and using the limits of the box with the coefficient 1.5 for the outlier values.

The volume of $\mathrm{CH}_{4}$ produced in each triplicate was tested to verify whether these three values could be considered from the same population. First, the Shapiro-Wilk test was used to verify the normality of the data distribution. Then, the Kruskal-Wallis test was used to confirm the triplicate results. Triplicates for STP5 and STP6 and duplicates for STP1, STP2, STP3 and STP4 showed a significance level of 0.05 . This set of data was used to adjust the Boltzmann equation. The Pearson method was used to correlate the SMA and trace metal fractionation. The confidence interval was plotted at a significance level of 0.05 .

\section{Results and discussion}

\subsection{Total metal content in sewage sludge}

The total metal contents for each metal are presented in Fig. 1. The mean value of the $\mathrm{Ni}$ content was $157 \mathrm{mg} \mathrm{kg} \mathrm{TS}{ }^{-1}$; this value varied greatly in the STP3 and STP5 samples, with values of 302 and $374 \mathrm{mg} \mathrm{kg} \mathrm{TS}{ }^{-1}$, respectively; however, they are not considered outliers (Fig. 1A). The values of Ni in the STP3 and STP5 samples are close to the maximum amount allowed (MAA, $420 \mathrm{mg} \mathrm{kg} \mathrm{TS}^{-1}$ ) for sludge reuse as fertilizer in Brasil (2006). Any increase in Ni accumulation in STP3 and STP5 may cause limitations for further sludge disposal. The Box-Whiskers graph of the Mn content demonstrated a small variation among the sludges, with a standard error of $12 \%$ around the mean value of $98 \mathrm{mg} \mathrm{kg} \mathrm{TS}^{-1}$ (Fig. 1A). The content of Se in STP3, $46 \mathrm{mg} \mathrm{kg} \mathrm{TS}^{-1}$, was the highest and was considered an outlier compared with the mean value of $21 \mathrm{mg} \mathrm{kg} \mathrm{TS}^{-1}$ (Fig. 1A); however, it was less than half of the MAA in Brazil $\left(100 \mathrm{mg} \mathrm{kg} \mathrm{TS}^{-1}\right)$. The Co content measured in the samples had a mean value of $7 \mathrm{mg} \mathrm{kg} \mathrm{TS}^{-1}$ and an SE of $16 \%$ around the mean (Fig. 1A). The Fe content in the sewage sludge samples had a mean of $10,560 \mathrm{mg} \mathrm{kg} \mathrm{TS}{ }^{-1}$ (Fig. 1B); the STP5 sample contained $23,260 \mathrm{mg} \mathrm{kg} \mathrm{TS}^{-1}$ and was considered an outlier. The $\mathrm{Zn}$ content measured in the samples varied greatly, with an SE of $93 \%$ around the mean value of $1300 \mathrm{mg} \mathrm{kg} \mathrm{TS}^{-1}$; however, none of these sample results was considered an outlier (Fig. 1B). The STP6 sample had a total $\mathrm{Zn}$ concentration of $2580 \mathrm{mg} \mathrm{kg} \mathrm{TS}{ }^{-1}$, which was close to the MAA value of $2800 \mathrm{mg} \mathrm{kg} \mathrm{TS}^{-1}$.

The mean value of $\mathrm{Pb}$ in the samples was $28 \mathrm{mg} \mathrm{kg} \mathrm{TS}^{-1}$, and the SE was $11.5 \%$ around the mean (Fig. $1 \mathrm{~A}$ ). The Pb values in all samples were lower than the MAA (300 $\mathrm{mg} \mathrm{kg} \mathrm{TS}{ }^{-1}$ ); thus, the content of this heavy metal did not limit the reuse of the sewage sludge in agricultural applications. The mean value of the $\mathrm{Cr}$ content was $132 \mathrm{mg} \mathrm{kg} \mathrm{TS}^{-1}$ (Fig. 1A), and although the STP5 sample contained $314 \mathrm{mg} \mathrm{kg} \mathrm{TS}^{-1}$, which is considered an outlier, all samples had values lower than the MAA of $1000 \mathrm{mg} \mathrm{kg} \mathrm{TS}^{-1}$. The $\mathrm{K}$ content mean value was $791 \mathrm{mg} \mathrm{kg} \mathrm{TS}^{-1}$ with an SE of 9.6\% (Fig. 1B); however, STP6 contained $1107 \mathrm{mg} \mathrm{kg} \mathrm{TS}{ }^{-1}$, which could be considered an outlier. The mean value of $\mathrm{Cu}$ was $714 \mathrm{mg} \mathrm{kg} \mathrm{TS}^{-1}$ (Fig. 1B), and the highest value of $1539 \mathrm{mg} \mathrm{kg} \mathrm{TS}^{-1}$ was observed in the STP3 sample, which was an outlier among the samples and limited the reuse of this sludge because the MAA for $\mathrm{Cu}$ is $1500 \mathrm{mg} \mathrm{kg} \mathrm{TS}^{-1}$.

Souza et al. (2014) analyzed the total metal content in sludge from the UASB of an STP located in Brazil. Their data for sludge sampling in dry and rainy seasons, except for $\mathrm{Cu}$, are similar from those obtained in this study: Ni concentration varying from 53.94 to $62.26 \mathrm{mg} \mathrm{kg} \mathrm{TS}^{-1}, \mathrm{Zn}$ concentration varying from 968.51 to $1454.23 \mathrm{mg} \mathrm{kg} \mathrm{TS}{ }^{-1}$, $\mathrm{Cr}$ concentration varying from 104.29 to $110.80 \mathrm{mg} \mathrm{kg} \mathrm{TS}^{-1}$, and $\mathrm{Pb}$ concentration varying from $<$ minimum detection limit to $6,79 \mathrm{mg} \mathrm{kg} \mathrm{TS}^{-1}$. De la Varga et al. (2013) evaluated the metal accumulation in the sludge of a pilot-scale UASB built in a STP in Spain. The authors measured metals in the sludge after 4 years of reactor operation and their results are similar from those obtained in this study for $\mathrm{Zn}, \mathrm{Fe}, \mathrm{Cu}, \mathrm{Ni}$ and $\mathrm{Co}$, i.e.,

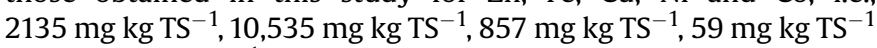
and $180 \mathrm{mg} \mathrm{kg} \mathrm{TS}^{-1}$, respectively. However, De la Varga et al. (2013) measured values for $\mathrm{Cr}$ and $\mathrm{Pb}$ concentration, 690 and $150 \mathrm{mg} \mathrm{kg} \mathrm{TS}{ }^{-1}$, respectively, higher than the values found in this study. The variability in the metal concentrations found in sewage sludge might be a result of the habits of the community served by the STP, the geological aspects of each region where the STP is
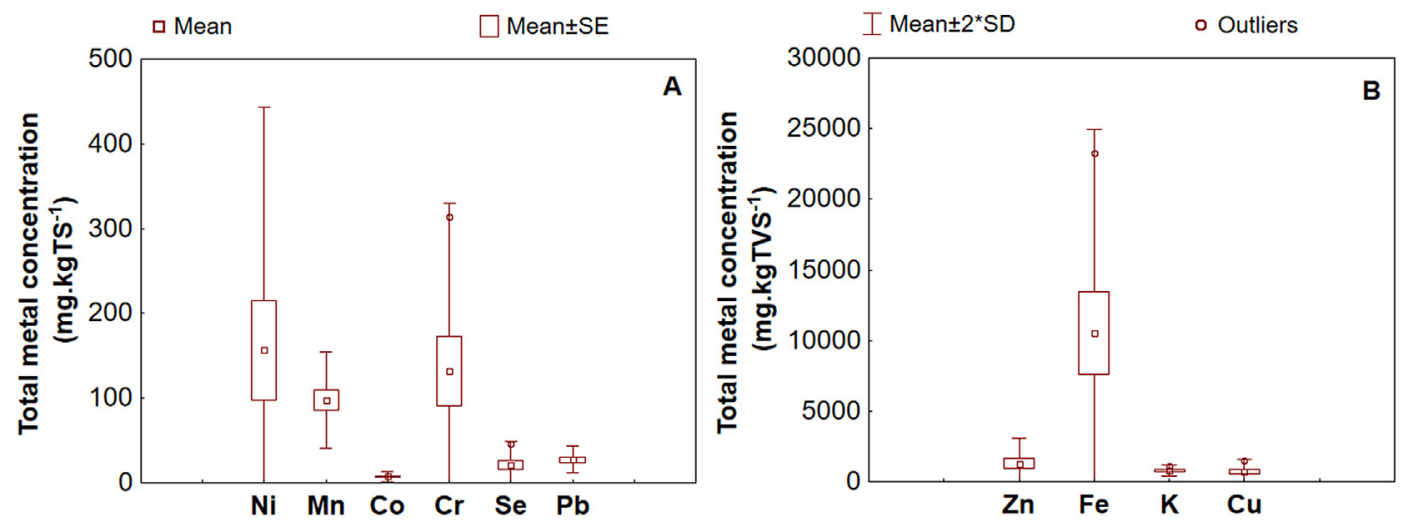

Fig. 1. Total TM content in sludge samples from UASBs treating domestic sewage. 
located because urban drainage water collected might go to the same treatment plant and the influent from industrial activities along the pipe system. However, the results found in the present study can indicate the order of magnitude of the total metal concentration in sewage sludge.

The sludge samples had an average total alkalinity (TA) and partial alkalinity (PA) of $45.69 \pm 35.32 \mathrm{mg} \mathrm{CaCO}_{3} \mathrm{~g} \mathrm{TS}^{-1}$ and $19.95 \pm 14.21 \mathrm{mg} \mathrm{CaCO}_{3} \mathrm{~g} \mathrm{TS}^{-1}$, respectively (Table 1 ). STP3 showed the highest TA and PA, and both parameters were considered statically extreme values; these high values were obtained because highly alkaline carbonate metal species are more likely to occur in the STP3 sludge than in the other studied sludges. The volatile acidity had an extreme value in the STP2. The average value of the intermediate alkalinity/total alkalinity ratio (IA/TA) was $0.55 \pm 0.06$. This value indicates that all the sludge samples have a buffering capacity to balance the $\mathrm{pH}$ during the acid production steps of anaerobic digestion (AD).

The total concentration of sulfur was also analyzed and is presented in Table 1. The average $S$ content in all sludges was $24.16 \pm 6.12 \mathrm{mg} \mathrm{S}$. TS $^{-1}$. STP5 was the only sample that presented S concentrations higher than the TA, which can affect the speciation of the metals present in the sludge. According to Oleszkiewicz and Sharma (1990), sulfide systems $\left(\mathrm{H}_{2} \mathrm{~S}_{(\mathrm{g})}-\mathrm{H}_{2} \mathrm{~S}_{(\mathrm{l})}-\mathrm{HS}^{-}-\mathrm{S}^{-2}\right)$ and carbonate systems $\left(\mathrm{CO}_{2(\mathrm{~g})}-\mathrm{CO}_{2(\mathrm{l})}-\mathrm{HCO}_{3}^{-}-\mathrm{CO}_{3}^{-2}\right)$ are the most important for inorganic anions in acid-base and gas-liquid equilibria in anaerobic reactors. Van der Veen et al. [29] found that the sulfide system was predominant in anaerobic reactors, affecting the bioavailability of the TM once the metal sulfides attain a low solubility product. Therefore, STP5 might present a higher content of TM bound to sulfides than carbonates compared to the other sludge samples.

\subsection{Single metal fractionation in the sewage sludges}

\subsubsection{Nickel}

STP1, STP2, STP4 and STP6 had Ni contents below $90 \mathrm{mg} \mathrm{kg} \mathrm{TS}{ }^{-1}$ (Fig. 2A). In contrast, STP3 and STP5 had Ni concentrations of 302 and $374 \mathrm{mg} \mathrm{kg} \mathrm{TS}{ }^{-1}$, respectively (Fig. 2A). Except for the two concentration clusters, the Ni fractionation of all samples was similar (Fig. 2A). Approximately $80 \%$ of the $\mathrm{Ni}$ is located in the $\mathrm{OM}+\mathrm{S}$ fraction, whereas $9-19 \%$ is in the RES fraction, and $1-10 \%$ is in the EXC and CARB combined fractions; thus, 90\% of the $\mathrm{Ni}$ is located in the less available fractions.

$\mathrm{Ni}$ is an essential trace metal for methanogenesis (Mulrooney and Hausinger, 2003). A Ni-containing enzyme, F430, is exclusively found in methanogens. Previous studies have shown $\mathrm{Ni}$ limitations in AD systems (Fermoso et al., 2008a; Pobeheim et al., 2011). The low availability of nickel in these sludges may lead to $\mathrm{Ni}$ limitations, although the total Ni concentration in some cases is close to the MAA value. Further research is required to prevent failure of these systems due to Ni limitations, considering that $\mathrm{Ni}$ addition might reach the MAA value in some cases.

\subsubsection{Manganese}

Mn is the most equally distributed metal among those studied (Fig. 2B). The total amount of $\mathrm{Mn}$ in the most available fractions (EXC and CARB) was from 15 to $42 \%$. The highest readily available Mn content was found in STP5 (28 $\left.\mathrm{mg} \mathrm{kg} \mathrm{TS}^{-1}\right)$, and the lowest in STP3 $\left(14 \mathrm{mg} \mathrm{kg} \mathrm{TS}^{-1}\right)$. The Mn content in the $\mathrm{OM}+\mathrm{S}$ fraction was from 31 to 53\%. Mn in the residual fraction, the less available fraction, was from $27 \%$ to $39 \%$. Mn is typically found in nature in its oxide and hydroxide forms, e.g., as manganite or braunite. The source of $\mathrm{Mn}$ in sewage may be related to discharge from industrial facilities or leachate from landfills and soils. Under anaerobic conditions, manganese is released from minerals and is reduced to its more soluble form, $\mathrm{Mn}(\mathrm{II})$. The release of $\mathrm{Mn}$ at its more soluble forms agrees with its distribution in anaerobic sludge. Mn, as shown by its fractionation, is a readily available metal; thus, its leaching from anaerobic digesters should not be considered a minor concern because $\mathrm{Mn}$, together with $\mathrm{Fe}$, contributes to water hardness, resulting in loss of pressure in the entire sewage cycle.

$\mathrm{Mn}$ is also an essential trace metal for methanogens. Mn acts as a stabilizer for the methyltransferase of methanogens (Oleszkiewicz and Sharma, 1990). The Mn requirement in the AD process has been previously reported, and its addition might be necessary in some cases (Wu et al., 2016).

\subsubsection{Selenium}

The percentage of Se in the $\mathrm{OM}+\mathrm{S}$ fraction was higher than $80 \%$ for all samples except for STP2 and STP5, with values of $45 \%$ and $61 \%$ in this fraction, respectively (Fig. 2C). The complementary Se percentage in STP2 and STP5 was mostly found in the RES fraction. In terms of Se content, STP2 had a value of $12 \mathrm{mg} \mathrm{kg} \mathrm{TS}^{-1}$ in the $\mathrm{OM}+\mathrm{S}$ fraction, and similar values were found in STP1, STP4 and STP6. STP5 contained only $4 \mathrm{mg} \mathrm{kg} \mathrm{TS}{ }^{-1}$ in the $\mathrm{OM}+\mathrm{S}$ fraction. STP3 showed the Se highest content, with a value of $46 \mathrm{mg} \mathrm{kg} \mathrm{TS}^{-1}$. Se is an essential metal for anaerobic digestion processes. Zhang et al. (2015)reported that Se deficiency resulted in the accumulation of acetic and propionic acids in the anaerobic digestion of food waste.

\subsubsection{Cobalt}

Co has been shown to play a crucial role in the anaerobic digestion pathway. Co limitation in many anaerobic digesters has been reported (Banks et al., 2012; Fermoso et al., 2008b; Gustavsson et al., 2013a). Co toxicity in an AD system has also been reported (Bartacek et al., 2008). The Co concentration that causes limitations is not far from the Co concentration that promotes toxicity (Bartacek et al., 2008). The fractionation of cobalt is especially relevant because the change of cobalt to more available fractions might decrease the metal limitation, but it might reach toxic concentrations if improved availability occurs.

Co is present at very low concentrations compared to any of the studied metals (Fig. 2D). STP5 had 63\% (4 mg kg TS ${ }^{-1}$ ) of Co content in the EXC fraction. STP1 had 39\% of Co in the EXC fraction, with value of $2 \mathrm{mg} \mathrm{kg} \mathrm{TS}^{-1}$, and STP4 had $48 \%$ of Co in this fraction, with value of $5 \mathrm{mg} \mathrm{kg} \mathrm{TS}^{-1}$. In the STP2, 77\% of Co content $\left(7 \mathrm{mg} \mathrm{kgTS}^{-1}\right)$ was found in the CARB fraction. STP3 and STP6 had the highest Co percentage in the $\mathrm{OM}+\mathrm{S}$ fraction, with values of 2 and $6 \mathrm{mg} \mathrm{kg} \mathrm{TS}^{-1}$, representing 76\% and 61\%, respectively. Cobalt was primarily found in the EXC and CARB fractions in four of the six sludges, while the other studied metals were primarily present in the $\mathrm{OM}+\mathrm{S}$ and RES fractions. The distribution of cobalt is interesting because it is expected to be found primarily in the $\mathrm{OM}+\mathrm{S}$ fraction, as was observed for nickel, considering the formation of different cobalt sulfide precipitates that would promote the anaerobic environment.

Gustavsson et al. (2013b) evaluated the speciation of $\mathrm{Ni}$, Co and Fe supplementation in the sludge of semi continuous stirred tank reactors (SCSTR) fed with grain stillage to verify the bioavailability of the trace metals after its supplementation. The authors used the modified Tessier method and found that Ni had low bioavailability and $\mathrm{Co}$ was primarily linked to the $\mathrm{OM}+\mathrm{S}$ fraction but also had a high content in the liquid phase of the sludge.

\subsubsection{Iron}

The Fe content in the EXC and CARB fractions varied from 1 to $15 \%$ in the samples analyzed, with a maximum concentration of $734 \mathrm{mg} \mathrm{kg} \mathrm{TS}^{-1}$ found in the STP2 (Fig. 2E). The RES fraction contained approximately $35 \%$ of the Fe measured in the samples, with 


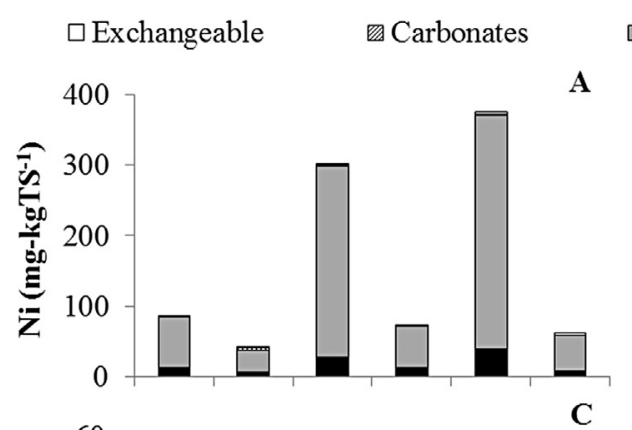

$\square$ Organic matter/ sulfides

- Residual
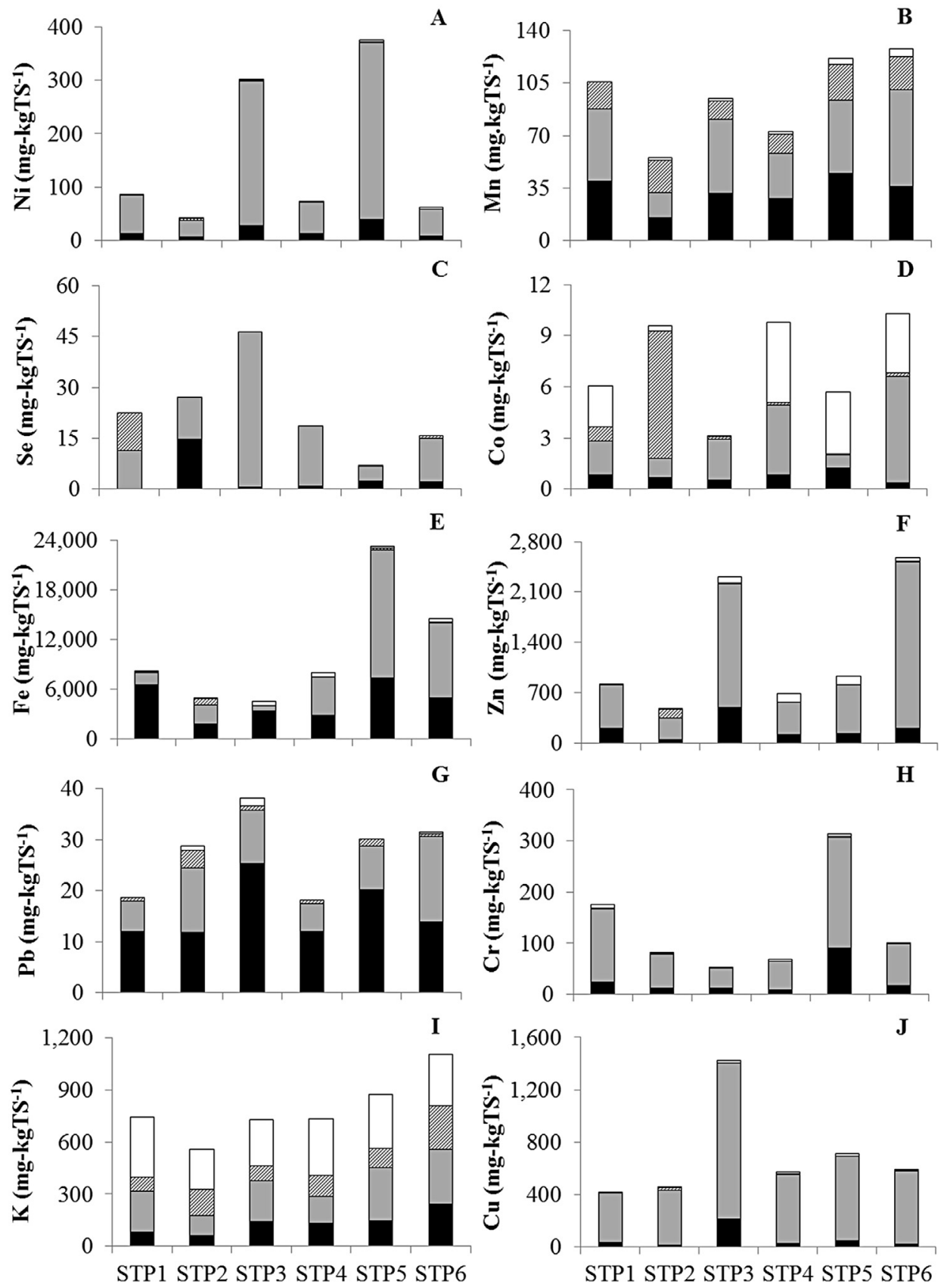

Fig. 2. Metal fractionation of the sludge samples.

the exception of STP1 and STP3, which showed 80 and 75\%, respectively. STP5 and STP6 contained 15,480 and $9000 \mathrm{mg} \mathrm{kg} \mathrm{TS}^{-1}$ in the $\mathrm{OM}+\mathrm{S}$ fraction, representing approximately $65 \%$ of the measured Fe.

Fe is an essential metal for anaerobic microorganisms and can be considered a macronutrient because it is required at higher concentrations than other trace metals. Fe is present as an enzyme cofactor related to the acidogenic step of anaerobic digestion, such as Fe-Fe hydrogenase (Vignais and Colbeau, 2004), but it is also directly related to methane production, such as in methane monooxygenase (Fermoso et al., 2009). According to Takashima et al. (2011), the Fe requirement is higher for the anaerobic digestion of glucose than for the anaerobic digestion of acetate, indicating that it is more related to the acidogenesis and acetogenesis steps of substrate degradation than to methanogenesis.

Fe can precipitate in anaerobic reactors as $\mathrm{FeCO}_{3}$, with an apparent solubility of $10^{-9} \mathrm{mmol} . \mathrm{L}^{-1}$, due the presence of carbonates Langerak et al. (1999). It can also precipitate as $\mathrm{Fe}_{3}\left(\mathrm{PO}_{4}\right)_{2}$ due to the reaction with phosphate, and as compounds formed with sulfur (FeS), Fe-thiol and other compounds due interactions with inorganic and organic forms of sulfur, as stated by Yekta et al. (2014).

\subsubsection{Zinc}

The highest percentage of zinc was in the $\mathrm{OM}+\mathrm{S}$ fraction in all samples, with an average of $73 \pm 9 \%$ (Fig. 2F). The RES fraction accounted for $16 \pm 7 \%$, on average, of the $\mathrm{Zn}$ content in the samples. 

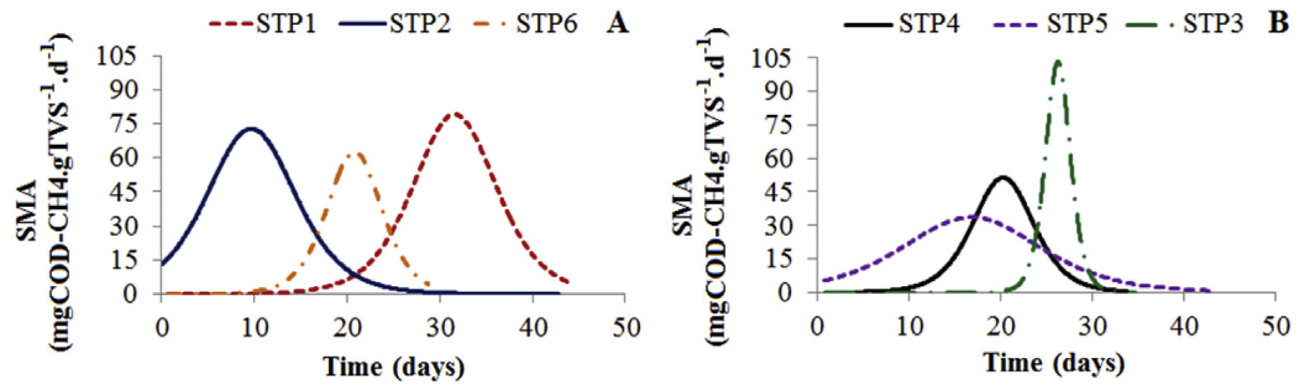

Fig. 3. Specific methanogenic activity of the sludge using the adjusted Boltzmann equation.

$\mathrm{Zn}$ in the EXC and CARB fractions varied from 1 to $25 \%$. The formation of stable zinc sulfide precipitates is most likely the cause of the high percentage of $\mathrm{Zn}$ in the $\mathrm{OM}+\mathrm{S}$ fraction. A 2-fold $\mathrm{Zn}$ content was found in STP6 (2580 $\mathrm{mg} \mathrm{kg} \mathrm{TS}^{-1}$ ) and STP3 (2320 $\left.\mathrm{mg} \mathrm{kg} \mathrm{TS}^{-1}\right)$ compared with the other sludge samples.

$\mathrm{Zn}$ is involved with the enzymes that catalyze the alkyl transfer to thiols (Penner-Hahn, 2007). This reaction is involved in the degradation pathway of anaerobic digestion. $\mathrm{Zn}$ limitation has been reported to promote failure of the anaerobic digestion process
(Fermoso et al., 2008). Zn limitation is not expected to occur in the sludges in the present study because of its high concentration in the EXC and CARB fractions in all sludges (Fig. 2F).

\subsubsection{Lead}

Approximately $66 \%$ of the Pb was contained in the RES fraction, except for the STP2 and STP6 samples, which had approximately $42 \% \mathrm{~Pb}$ in this fraction (Fig. 2G). Approximately 29\% of $\mathrm{Pb}$ was contained in the $\mathrm{OM}+\mathrm{S}$ fraction for all samples, except for STP2 and
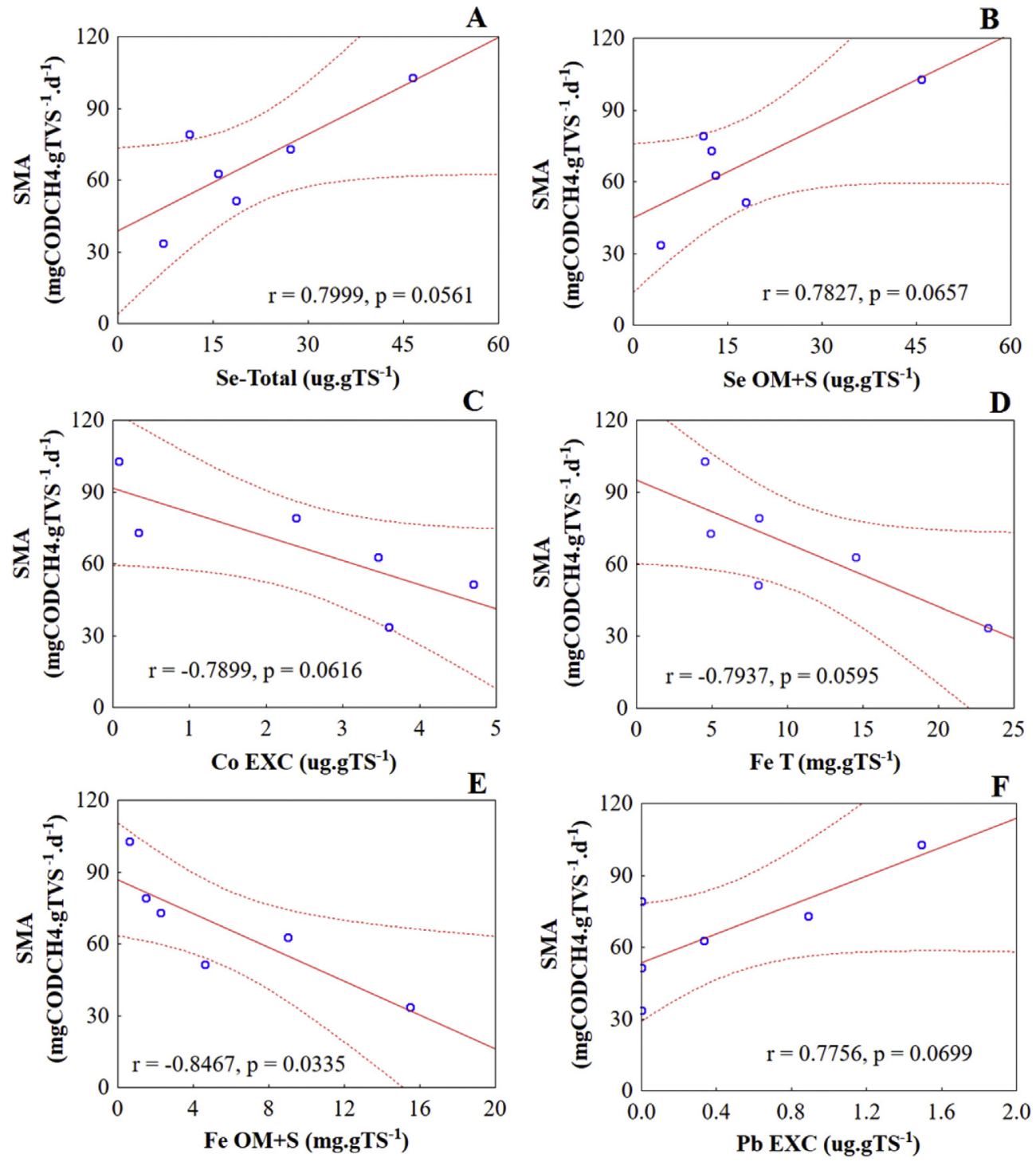

Fig. 4. Correlation between SMA and metal fractionation. 
STP6, which had 44 and $54 \%$ of PB in the OM + S fraction, respectively. The range of the total $\mathrm{Pb}$ measured in the samples was narrower, with values from 17 to $38 \mathrm{mg} \mathrm{kg} \mathrm{TS}^{-1}$.

Lead has no essential function in anaerobic metabolism. However, at high concentrations, $\mathrm{Pb}$ can inhibit microorganism activity by hindering enzymes or causing the loss of their function. Heavy metals, such as $\mathrm{Pb}$, are nonspecific and noncompetitive inhibitors; they bind either with enzymes or the enzyme substrate complex (Oleszkiewicz and Sharma, 1990). However, authors (Lin and Lin, 1997; Lin and Chen, 1999; Mudhoo and Kumar, 2013) observed that $\mathrm{Pb}$ was a less toxic metal for the methanogenic process than $\mathrm{Cu}, \mathrm{Cr}, \mathrm{Cd}, \mathrm{Zn}$ and $\mathrm{Ni}$. Lin and Chen (1999) found that the Pb concentration that inhibits $50 \%$ of methane production (IC50) is approximately $8440 \mathrm{mg} . \mathrm{L}^{-1}$. Regarding the reuse of sludge, the $\mathrm{Pb}$ content measured in the samples analyzed was more than 10 times lower than the maximum allowed in Brazil (Brasil, 2006), and more than $90 \%$ of $\mathrm{Pb}$ was in the two less available fractions, i.e., the $\mathrm{OM}+\mathrm{S}$ and RES fractions.

\subsubsection{Chromium}

The major $\mathrm{Cr}$ percentage was found in the $\mathrm{OM}+\mathrm{S}$ fraction, with an average value of $78 \pm 6 \%$, and the RES fraction contained an average of $19 \pm 6 \%$ (Fig. $2 \mathrm{H}$ ). The sludge fractionation of $\mathrm{Cr}$ was similar for all samples. However, the total $\mathrm{Cr}$ in STP5 was 7 times higher (314 $\mathrm{mg} \mathrm{kg} \mathrm{TS}^{-1}$ ) than the value measured in STP3, which had the samples with the lowest $\mathrm{Cr}$ content.

$\mathrm{Cr}$ exists in several forms. $\mathrm{Cr}$ (III) occurs naturally, whereas $\mathrm{Cr}(0)$ and $\mathrm{Cr}(\mathrm{VI})$ are produced by industries. $\mathrm{Cr}(\mathrm{VI})$ is widely used in textile industries to dye wool and to tan leather. Textile-related industries are most likely the $\mathrm{Cr}$ source in STP5. There is no $\mathrm{Cr}$ requirement by anaerobic microorganisms because it only acts as an inhibitor, similar to $\mathrm{Pb}$. However, $\mathrm{Cr}$ has more inhibitory potential than Pb. Lin and Chen (1999) found that the average IC50 value for $\mathrm{Cr}$ was ninety times higher than the value for $\mathrm{Pb}$.

\subsubsection{Potassium}

On average, $41 \pm 5 \%$ of $\mathrm{K}$ was found in the EXC fraction in the samples, except for the STP6 sample, which had 27\% in this fraction (Fig. 2I). The STP6 presented an almost equally distribution of $\mathrm{K}$ among the fractions, with values of $23 \%$ in CARB, $29 \%$ in OM+S and $22 \%$ in RES. Approximately $33 \%$ of the $\mathrm{K}$ was found in the $\mathrm{OM}+\mathrm{S}$ fraction in STP1, STP3 and STP5, whereas $21 \%$ of $\mathrm{K}$ was present in this fraction for STP2 and STP4. The RES fraction contained below $22 \%$ of the total $\mathrm{K}$.

$\mathrm{K}$ is considered a macronutrient because it is required in large amounts for several microorganisms. $\mathrm{K}$ acts to regulate cell permeability, thus balancing the transport of nutrients and cations (Scherer et al., 1983). Chen and Cheng (2007) demonstrated that $\mathrm{K}$ can also inhibit methane production at concentrations over $3 \mathrm{~g} \mathrm{~L}^{-1}$ when the biomass has not adapted, and Wu et al. (2016) noted that more studies about $\mathrm{K}$ requirements are needed.

\subsubsection{Copper}

The copper percentages in the fractionation were similar for all samples. Cu was found at values over $85 \%$ in the $\mathrm{OM}+\mathrm{S}$ fraction for all the samples analyzed; in the RES fraction, it was found from 3 to $14 \%$, and a maximum value of $5 \%$ was found in the EXC and CARB fractions. However, the total content of $\mathrm{Cu}$ in the STP3 samples was 2-fold higher than STP5, 3-fold higher than STP2, STP4 and STP6 and 4-fold higher than SPT1. The jewelry-related industries and metallurgical factories might be the Cu source in STP3 because they are present in that region.

According to Glass and Orphan (2012), no enzymes related to methane production were identified as $\mathrm{Cu}$-dependent, even though it is an important metal for aerobic methanotrophy and archaeal ammonia oxidation. However, $\mathrm{Cu}$ is necessary in the acidogenesis step of anaerobic digestion in which $\mathrm{Cu}$ is linked to the hydrogenase of facultative anaerobes and Clostridia (Oleszkiewicz and Sharma, 1990). Additionally, inhibition of anaerobic microorganisms due to Cu was studied by Lin and Chen (1999), and it was shown to be the most toxic metal for volatile fatty acid (VFA) and methane production among $\mathrm{Cd}, \mathrm{Cr}, \mathrm{Ni}, \mathrm{Zn}$ and $\mathrm{Pb}$.

\subsection{Evaluation of the sludge SMA}

Methane production was measured, and the SMA curves calculated from this data are presented in Fig. 3. The SMA of the different sludge samples had different values, as the time required to reach the maximum SMA was different for the samples, with values ranging from 10 to 30 days and reaching the maximum SMA from 33 to $103 \mathrm{mg}$ COD-CH 4 g TVS $^{-1} \mathrm{~d}^{-1}$. The different values might be attributed to several factors, such as substrate adaptation and inoculum composition, among others. The concentration of the different trace metals is only one additional parameter that might affect the microbial activity.

Although the SMA for STP1, STP2 and STP6 was only slightly different regarding the maximum SMA value (Fig. 3A, Table 4), the time required to reach this value was clearly different. STP6 required 20.8 days to reach the maximum SMA, STP2 only needed 9.7 days. STP3 showed the highest maximum value out of the six samples, i.e., 103 mgCOD-CH 4 gTVS $^{-1} \mathrm{~d}^{-1}$, and STP5 showed the lowest value, i.e., 33.67 (Fig. 3B, Table 4). These values are in contrast to the time required to reach the maximum SMA value. STP3 required 26.3 days to reach the maximum SMA, while STP5 only required 16.8 days (Fig. 3B, Table 4 ). The time when no activity was measured in the STP3 sludge could have been influenced by the time required to release essential metals. STP3 contained Se, Ni, Zn and $\mathrm{Cu}$ at higher concentrations compared to the other sludge samples; however, they were primarily in the $\mathrm{OM}+\mathrm{S}$ fraction. The low SMA value of the STP5 sludge might be influenced by $\mathrm{Cr}$ because it is present in the STP5 sludge at a much higher concentration than in the other sludge samples (Fig. $2 \mathrm{H}$ ).

\subsection{Correlation between SMA and metal fractionation}

Although the metal concentration cannot be initially considered a cause/effect factor for SMA values from different sludges, some indications can be drawn from it. A correlation study between the total metals and the metal fractions against the SMA values was performed. Fig. 4 shows the six of fifty correlations that had an $r$ value higher than 0.75 . One of the six correlations was statistically significant, and the remaining nearly reached statistical significance (Fig. 4).

A positive correlation was observed between total Se and SMA. $\mathrm{Se}$ in the sludges was primarily present in the $\mathrm{OM}+\mathrm{S}$ fraction; therefore, a correlation of this metal to SMA was observed for both the total and $\mathrm{OM}+\mathrm{S}$ fraction. Interestingly, a negative correlation

Table 4

Parameters of the Boltzmann model (average adjusted $R^{2}=0.9833$ ).

\begin{tabular}{lll}
\hline Sludge & $\mathrm{t}_{\mathrm{SMA}}{ }^{\mathrm{a}}(\mathrm{d})$ & $\mathrm{SMA}^{\mathrm{b}}\left(\mathrm{mgCOD}_{\mathrm{CH} 4} \mathrm{gTVS}^{-1} \mathrm{~d}^{-1}\right)$ \\
\hline STP1 & 31.6 & 79.30 \\
STP2 & 9.7 & 72.94 \\
STP3 & 26.3 & 103.00 \\
STP4 & 20.3 & 51.35 \\
STP5 & 16.8 & 33.67 \\
STP6 & 20.8 & 62.87 \\
\hline
\end{tabular}

a Time to reach the maximum SMA.

b Specific methanogenic activity. 
with the SMA was observed for Co in the EXC fraction. Co is an important essential metal, and at a high concentration, it inhibits the anaerobic process. In the present study, it was observed that although Co was found at a low total concentration, the Co concentration in the EXC fraction was most likely sufficient to promote the inhibition of the anaerobic process. The total Fe also shows a negative correlation with the SMA (Fig. 4D). The same correlation was observed for the Fe concentration in the $\mathrm{OM}+\mathrm{S}$ fraction, with an even higher statistical significance (Fig. 4E). Indications can be inferred for the negative correlation with Fe, e.g., Gustavsson et al. (2013b) stated that the presence of Fe can contribute to the coprecipitation of other trace metals in an environment dominated by a sulfide system, which might lower the bioavailability of these trace metals.

There was a positive correlation between $\mathrm{Pb}$ in the EXC fraction and SMA. Because $\mathrm{Pb}$ is not an essential metal, an increase in SMA due to an increase in $\mathrm{Pb}$ in the EXC fraction should not be possible. It could be hypothesized that a competition between $\mathrm{Pb}$ and more toxic metals may favor an increase in SMA. However, there was no $\mathrm{Pb}$ inhibition at the $\mathrm{Pb}$ concentrations found in the sludges in this study.

\section{Conclusions}

The total trace metal concentration in the six studied sludges had values of the same order of magnitude for $\mathrm{Mn}, \mathrm{Co}, \mathrm{Pb}$ and $\mathrm{K}$. However $\mathrm{Ni}, \mathrm{Se}, \mathrm{Fe}, \mathrm{Zn}, \mathrm{Cr}$ and $\mathrm{Cu}$ showed a difference between samples higher than four-fold.

Fractionation of the different trace metals was not equally distributed in the six studied sludges. The organic matter and sulfide fraction was the primary fraction containing the studied metals; however, for some metals, such as Co or K, the exchangeable and carbonate fractions also showed high values.

As expected, the SMA of the different sludges was not directly correlated to the metal or metal fractions in the present study. However, indications were found for trace metal effects.

\section{Acknowledgments}

This research was funded by the Conselho Nacional de Desenvolvimento Científico e Tecnológico (CNPq - Processes 406751/ 2013-7, 150521/2014-6 and 150641/2015-0).

\section{References}

Angelidaki, I., Alves, M., Bolzonella, D., Borzacconi, L., Campos, J.L., Guwy, a J., Kalyuzhnyi, S., Jenicek, P., van Lier, J.B., 2009. Defining the biomethane potential (BMP) of solid organic wastes and energy crops: a proposed protocol for batch assays. Water Sci. Technol. 59, 927-934. http://dx.doi.org/10.2166/ wst.2009.040.

APHA, AWWA, WEF, 2005. Standard Methods for the Examination of Water and Wastewater, twenty-first ed. American Public Health Association, Washington, DC.

Banks, C.J., Zhang, Y., Jiang, Y., Heaven, S., 2012. Trace element requirements for stable food waste digestion at elevated ammonia concentrations. Bioresour. Technol. 104, 127-135. http://dx.doi.org/10.1016/j.biortech.2011.10.068.

Bartacek, J., Fermoso, F.G., Baldó-Urrutia, A.M., van Hullebusch, E.D., Lens, P.N.L. 2008. Cobalt toxicity in anaerobic granular sludge: influence of chemical speciation. J. Ind. Microbiol. Biotechnol. 35, 1465-1474. http://dx.doi.org/ 10.1007/s10295-008-0448-0.

Bizzi, C. a., Flores, E.L.M., Nóbrega, J. a., Oliveira, J.S.S., Schmidt, L., Mortari, S.R., 2014 Evaluation of a digestion procedure based on the use of diluted nitric acid solutions and $\mathrm{H} 2 \mathrm{O} 2$ for the multielement determination of whole milk powder and bovine liver by ICP-based techniques. J. Anal. At. Spectrom. 29, 332. http:// dx.doi.org/10.1039/c3ja50330e.

Brasil, 2006. Conselho Nacional do Meio Ambiente. Resolução no. 375. Brasil.

Brasil, 2011. Conselho Nacional do Meio Ambiente. Resolução no. 430. Brasil.

Chen, Y., Cheng, J.J., 2007. Effect of potassium inhibition on the thermophilic anaerobic digestion of swine waste. Water Environ. Res. 79, 667-674. http:// dx.doi.org/10.2175/106143007X156853.

Chernicharo, C.A.L., Lier, J.B., Noyola, A., Ribeiro, T.B., 2015. Anaerobic sewage treatment: state of the art, constraints and challenges. Rev. Environ. Sci. Bio Technol. 14, 649-679. http://dx.doi.org/10.1007/s11157-015-9377-3.

Chong, S., Sen, T.K., Kayaalp, A., Ang, H.M., 2012. The performance enhancements of upflow anaerobic sludge blanket (UASB) reactors for domestic sludge treatmen - a State-of-the-art review. Water Res. 46, 3434-3470. http://dx.doi.org 10.1016/j.watres.2012.03.066.

De la Varga, D., Díaz, M.A., Ruiz, I., Soto, M., 2013. Heavy metal removal in an UASBCW system treating municipal wastewater. Chemosphere 93, 1317-1323. http://dx.doi.org/10.1016/j.chemosphere.2013.07.043.

DilLallo, R., Albertson, O.E., 1961. Volatile acids by direct titration. J. Water Pollut Control Fed. 33, 356-365.

Fermoso, F.G., Bartacek, J., Jansen, S., Lens, P.N.L., 2009. Metal supplementation to UASB bioreactors: from cell-metal interactions to full-scale application. Sci. Total Environ. 407, 3652-3667. http://dx.doi.org/10.1016 j.scitotenv.2008.10.043.

Fermoso, F.G., Bartacek, J., Manzano, R., van Leeuwen, H.P., Lens, P.N.L., 2010. Dosing of anaerobic granular sludge bioreactors with cobalt: impact of cobalt retention on methanogenic activity. Bioresour. Technol. 101, 9429-9437. http:// dx.doi.org/10.1016/j.biortech.2010.07.053.

Fermoso, F.G., Collins, G., Bartacek, J., Lens, P.N.L., 2008. Zinc deprivation of methanol fed anaerobic granular sludge bioreactors. J. Ind. Microbiol. Biotechnol. 35, 543-557. http://dx.doi.org/10.1007/s10295-008-0315-z.

Fermoso, F.G., Collins, G., Bartacek, J., O'Flaherty, V., Lens, P., 2008a. Role of nickel in high rate methanol degradation in anaerobic granular sludge bioreactors. Biodegradation 19, 725-737. http://dx.doi.org/10.1007/s10532-008-9177-3.

Fermoso, F.G., Collins, G., Bartacek, J., O'Flaherty, V., Lens, P., 2008b. Acidification of methanol-fed anaerobic granular sludge bioreactors by cobald deprivation: induction and microbial community dynamics. Biotechnol. Bioeng. 99, 49-58. http://dx.doi.org/10.1002/bit.21528.

Filgueiras, a.V., Lavilla, I., Bendicho, C., 2002. Chemical sequential extraction for metal partitioning in environmental solid samples. J. Environ. Monit. 4, 823-857. http://dx.doi.org/10.1039/b207574c.

Florencio, L., Jeniček, P., Field, J. a., Lettinga, G., 1993. Effect of cobalt on the anaerobic degradation of methanol. J. Ferment. Bioeng. 75, 368-374. http:// dx.doi.org/10.1016/0922-338X(93)90136-V.

Foresti, E., Zaiat, M., Vallero, M., 2006. Anaerobic processes as the core technology for sustainable domestic wastewater treatment: consolidated applications, new trends, perspectives, and challenges. Rev. Environ. Sci. Biotechnol. 5, 3-19. http://dx.doi.org/10.1007/s11157-005-4630-9.

Foresti, L., 2002. Anaerobic treatment of domestic sewage: established technologies and perspectives. Water Sci. Technol. 45, 181-186.

Glass, J.B., Orphan, V.J., 2012. Trace metal requirements for microbial enzymes involved in the production and consumption of methane and nitrous oxide. Front Microbiol. 3, 61. http://dx.doi.org/10.3389/fmicb.2012.00061.

Gustavsson, J., Shakeri Yekta, S., Sundberg, C., Karlsson, A., Ejlertsson, J. Skyllberg, U., Svensson, B.H., 2013a. Bioavailability of cobalt and nickel during anaerobic digestion of sulfur-rich stillage for biogas formation. Appl. Energy 112, 473-477. http://dx.doi.org/10.1016/j.apenergy.2013.02.009.

Gustavsson, J., Yekta, S.S., Karlsson, A., Skyllberg, U., Svensson, B.H., 2013b. Potentia bioavailability and chemical forms of $\mathrm{Co}$ and $\mathrm{Ni}$ in the biogas process-An evaluation based on sequential and acid volatile sulfide extractions. Eng. Life Sci. 13, 572-579. http://dx.doi.org/10.1002/elsc.201200162.

van Hullebusch, E.D., Utomo, S., Zandvoort, M.H., Lens, P.N.L., 2005. Comparison of three sequential extraction procedures to describe metal fractionation in anaerobic granular sludges. Talanta 65, 549-558. http://dx.doi.org/10.1016 j.talanta.2004.07.024.

Jones, V., Gardner, M., Ellor, B., 2014. Concentrations of trace substances in sewage sludge from 28 wastewater treatment works in the UK. Chemosphere 111, 478-484. http://dx.doi.org/10.1016/j.chemosphere.2014.04.025.

Jordão, E.P., Volschan, I., 2004. Cost-effective solutions for sewage treatment in developing countries - the case of Brazil. Water Sci. Technol. 50, 237-242.

Khan, A.A., Gaur, R.Z., Tyagi, V.K., Khursheed, A., Lew, B., Mehrotra, I., Kazmi, A.A. 2011. Sustainable options of post treatment of UASB effluent treating sewage: a review. Resour. Conserv. Recycl. 55, 1232-1251. http://dx.doi.org/10.1016 j.resconrec.2011.05.017.

Kida, K., Shigematsu, T., Kijima, J., Numaguchi, M., Mochinaga, Y., Abe, N., Morimura, S., 2001. Influence of $\mathrm{Ni2}+$ and $\mathrm{Co} 2+$ on methanogenic activity and the amounts of coenzymes involved in methanogenesis. J. Biosci. Bioeng. 91, 590-595.

Van Langerak, E.P.a, Beekmans, M.M.H., Beun, J.J., Hamelers, H.V.M., Lettinga, G., 1999. Influence of phosphate and iron on the extent of calcium carbonate precipitation during anaerobic digestion. J. Chem. Technol. Biotechnol. 74 1030-1036. http://dx.doi.org/10.1002/(SICI)1097-4660(199911)74:11<1030: AID-JCTB144>3.0.CO;2-L.

Lettinga, G., Roersma, R., Grin, P., 1983. Anaerobic treatment of raw domestic sewage at ambient temperatures using a granular bed UASB reactor. Biotechnol. Bioeng. 25, 1701-1723. http://dx.doi.org/10.1002/bit.260250703.

Lin, C., Lin, M., 1997. Effect of heavy metals on the upflow anaerobic sludge blanket process. J. Environ. Sci. Heal. Part A Environ. Sci. Eng. Toxicol. 32, 1933-1944. http://dx.doi.org/10.1080/10934529709376656.

Lin, C.Y., Chen, C.C., 1999. Effect of heavy metals on the methanogenic UASB granule Water Res. 33, 409-416. http://dx.doi.org/10.1016/S0043-1354(98)00211-5.

Liu, J., Sun, S., 2013. Total concentrations and different fractions of heavy metals in sewage sludge from Guangzhou, China. Trans. Nonferrous Met. Soc. China 23, 2397-2407. http://dx.doi.org/10.1016/S1003-6326(13)62747-8. 
Madigan, M.T., Martinko, J.M., Stahl, D.A., Clark, D.P., 2012. Brock Biology of Microorganisms, thirteenth ed. Benjamin Cummings, San Francisco.

Mudhoo, a., Kumar, S., 2013. Effects of heavy metals as stress factors on anaerobic digestion processes and biogas production from biomass. Int. J. Environ. Sci. Technol. 10, 1383-1398. http://dx.doi.org/10.1007/s13762-012-0167-y.

Mulrooney, S.B., Hausinger, R.P., 2003. Nickel uptake and utilization by microorganisms. FEMS Microbiol. Rev. 27, 239-261. http://dx.doi.org/10.1016/S01686445(03)00042-1.

Nogueirol, R.C., de Melo, W.J., Bertoncini, E.I., Alleoni, L.R.F., 2013. Concentrations of $\mathrm{Cu}, \mathrm{Fe}, \mathrm{Mn}$, and $\mathrm{Zn}$ in tropical soils amended with sewage sludge and composted sewage sludge. Environ. Monit. Assess. 185, 2929-2938. http:// dx.doi.org/10.1007/s10661-012-2761-3.

Oleszkiewicz, J. a., Sharma, V.K., 1990. Stimulation and inhibition of anaerobic processes by heavy metals: a review. Biol. Wastes 31, 45-67. http://dx.doi.org/ 10.1016/0269-7483(90)90043-R.

Penner-Hahn, J., 2007. Zinc-promoted alkyl transfer: a new role for zinc. Curr. Opin Chem. Biol. 11, 166-171. http://dx.doi.org/10.1016/j.cbpa.2007.02.038.

Pobeheim, H., Munk, B., Lindorfer, H., Guebitz, G.M., 2011. Impact of nickel and cobalt on biogas production and process stability during semi-continuous anaerobic fermentation of a model substrate for maize silage. Water Res. 45 , 781-787. http://dx.doi.org/10.1016/j.watres.2010.09.001.

Ripley, L.E., Boyle, W.C., Converse, J.C., 1986. Improved alkalimetric monitoring for anaerobic digestion of high-strength wastes. J. Water Pollut. Control Fed. 58 406-411.

Scherer, P., Lippert, H., Wolff, G., 1983. Composition of the major elements and trace-elements of 10 methanogenic bacteria determined by inductively coupled plasma emission-spectrometry. Biol. Trace Elem. Res. 5, 149-163.

Secretaria Nacional de Saneamento Ambiental, 2014. Sistema nacional de informações sobre saneamento: Diagnóstico dos serviços de água e esgotos 2013. Brasília.

Souza, L.C.F., Canteras, F.B., Moreira, S., 2014. Analyses of heavy metals in sewage and sludge from treatment plants in the cities of Campinas and Jaguariúna, using synchrotron radiation total reflection X-rayfluorescence. Radiat. Phys. Chem. 95, 342-345. http://dx.doi.org/10.1016/j.radphyschem.2013.01.025.

Takashima, M., Shimada, K., Speece, R.E., 2011. Minimum requirements for trace metals (iron, nickel, cobalt, and zinc) in thermophilic and mesophilic methane fermentation from glucose. Water Environ. Res. 83, 339-346. http://dx.doi.org/ $10.2175 / 106143010 X 12780288628895$. van der Veen, a., Fermoso, F.G., Lens, P.N.L., 2007. Bonding form analysis of metals and sulfur fractionation in methanol-grown anaerobic granular sludge. Eng. Life Sci. 7, 480-489. http://dx.doi.org/10.1002/elsc.200720208.

Vignais, P.M., Colbeau, A., 2004. Molecular biology of microbial hydrogenases. Curr. Issues Mol. Biol. 6, 159-188.

Von Sperling, M., Oliveira, S.C., 2009. Comparative performance evaluation of fullscale anaerobic and aerobic wastewater treatment processes in Brazil. Water Sci. Technol. 59, 15-22. http://dx.doi.org/10.2166/wst.2009.841.

Worm, P., Fermoso, F.G., Lens, P.N.L., Plugge, C.M., 2009. Decreased activity of a propionate degrading community in a UASB reactor fed with synthetic medium without molybdenum, tungsten and selenium. Enzyme Microb. Technol. 45, 139-145. http://dx.doi.org/10.1016/j.enzmictec.2009.02.001.

Wu, L.-J., Kobayashi, T., Kuramochi, H., Li, Y.-Y., Xu, K.-Q., 2016. Effects of potassium, magnesium, zinc, and manganese addition on the anaerobic digestion of deoiled grease trap waste. Arab. J. Sci. Eng. 41, 2417. http://dx.doi.org/10.1007/ s13369-015-1879-3.

Yang, J., Lei, M., Chen, T., Gao, D., Zheng, G., Guo, G., Lee, D., 2014. Current status and developing trends of the contents of heavy metals in sewage sludges in China. Front. Environ. Sci. Eng. 8, 719-728. http://dx.doi.org/10.1007/s11783-0130600-6.

Yekta, S.S., Svensson, B.H., Björn, A., Skyllberg, U., 2014. Thermodynamic modeling of iron and trace metal solubility and speciation under sulfidic and ferruginous conditions in full scale continuous stirred tank biogas reactors. Appl. Geochem. 47, 61-73. http://dx.doi.org/10.1016/j.apgeochem.2014.05.001.

Zandvoort, M.H., Gieteling, J., Lettinga, G., Lens, P.N.L., 2004. Stimulation of methanol degradation in UASB reactors: in situ versus pre-loading cobalt on anaerobic granular sludge. Biotechnol. Bioeng. 87, 897-904. http://dx.doi.org/ 10.1002/bit.20200.

Zhang, W., Wu, S., Guo, J., Zhou, J., Dong, R., 2015. Performance and kinetic evaluation of semi-continuously fed anaerobic digesters treating food waste: role of trace elements. Bioresour. Technol. 178, 297-305. http://dx.doi.org/10.1016/ j.biortech.2014.08.046.

Zinatizadeh, a a L., Mohamed, a R., Abdullah, a Z., Mashitah, M.D., Hasnain Isa, M., Najafpour, G.D., 2006. Process modeling and analysis of palm oil mill effluent treatment in an up-flow anaerobic sludge fixed film bioreactor using response surface methodology (RSM). Water Res. 40, 3193-3208. http://dx.doi.org/ 10.1016/j.watres.2006.07.005. 